\title{
The Influence of Knowledgeable Planning Generation Program (GenRe) on Adolescent Attitude in Aceh Province, Indonesia
}

\author{
Rahmat Musfikar $^{1} \quad$ Eddy Munawar $^{2} \quad$ Fitrah Afandi $^{3} \quad$ Zulkifli $^{3} \quad$ Muslim A Djalil $^{3}$ \\ 1.PKP BEST, University of Syiah Kuala, Banda Aceh, Indonesia \\ 2.National Demography and Family Planning Board \\ 3.University of Syiah Kuala, Banda Aceh, Indonesia
}

\begin{abstract}
This study aims to determine the impact of adolescent knowledge about the Planning Generation Program or Generasi Berencana Program (GenRe) on adolescent attitudes. This study used a combination method with sequential explanatory design. 156 respondents were involved in this study. Data collection techniques were questionnaires in the form of close and open, as well as conducted in-depth interviews. Data collected The result of questionnaires was analyzed by using SPSS application with a simple regression technique by looking at the T test and F Test to see the results of the Hypothesis test. While the result of interview, the researchers used discovering culture themes analysis. The results of the study from the quantitative perspective concluded that Adolescent Knowledge about the Generasi Berencana Program is has a significant influence on Adolescent Attitudes.
\end{abstract}

Keywords: Planning Generation Program, Knowledge, Attitude, Adolescent

DOI: $10.7176 / J E S D / 10-2-17$

\section{Introduction}

Adolescence is a period of transition from childhood to maturity. According to the World Health Organization (WHO) in the Guidelines for Management of Adolescent Reproductive Health Information and Counseling Centers in 2006, adolescents are aged 10-19 years. The Regulation of the Minister of Health of the Republic of Indonesia Number 25 of 2014 notices that the range of 10-18 years old is regarding as adolescents. However, the rate of teenagers are concerned to 10-24 years old and unmarried yet based on the Population and Family Planning Board (BKKBN) view. Another perspective throughadolescenceaaccording toMeriis usually characterized by signs of puberty and physical changes that are complex, dramatic, and social adjustment whichare important for being an adult. Therefore, this condition makes adolescents lack of mental and thinking maturitybecause they are still seekingto their personal identity so that they are veryvulnerable to be influenced by social environment.

Various problems are often faced by adolescents. They are very susceptible to be affected in the Three Risks in Adolescent Reproductive Health (TRIAD KKR): Sexuality, HIV / AIDS, and Drugs) and also other stubborns in the form of minor and oppressive criminal (David and Dasminar, 2017). Dealing with adolescents and the problems that often occur, BKKBN developed the generasi berencana program for adolescents. This is supportedby the mandate of Government Law No.52 of 2009 concerning Population Development and Family Development article 48 verse 1 (b) that is well-said as, "Improving the quality of adolescents by providing access to information, education, counseling, and services about family life". The GenerasiBerencanaProgram aims to prepare and facilitate adolescents to have a betterplanning in family life. Therefore, they can learn to understand and practicethe inner physical and spirityualhealthylife behaviors, so that they can be nurtured as a high quality future generations who have good personalities in their character building. According to Wardhani (2012), the target of Generasi Berencana program is unmarried teenagers aged 10-24 years,students, college students, families, and communities who care about teenagers' interest. The Generasi Berencana program provides information and promotion about reproductive health such as supporting their self-awareness of preventing a too early getting married, keeping away from premarital sex, avoiding drug consumption, preparing a good life skill or developing a self-concept. This Program has been implemented by BKKBN since 2010 based on the regulations of the Head of the National Family Planning Coordinating Board Number 47 / HK.010 / B5 / 2010 and have been dissociated in various adolescents throughout the provinces of Indonesia including Aceh in order to overcome problems that occurred in adolescence. By having the socialiszation of thisprogram, the government hopes that there will be a positive impact on adolescent attitudes. Therefore, this research will examine the knowledge of adolescents about generasi berencana program and is there an influence of adolescent knowledge about generasi berencana program on adolescent attitudes in Aceh.

Based on the problem above, it can be formulated the problems in this study are; How many index adolescent knowledge about the generasi berencana program in Aceh Province? And How does the impact of knowledge about the generasi berencana on the adolescence attitude in Aceh Province?

The purpose of this study was to find out the index of adolescent knowledge about the generasi berencana program in Aceh Province and to find out whether there was a significant influence on the generasi berencana 
program from BKKBN on the adolescence attitude in Aceh Province.

\section{Literature Review}

This research is based on the framework of thinking that comes from a reality life especially for Acehnese society. It can be assumed that the level of adolescent problems that is emerged ranging from free sex, drugs, or even HIV / AIDS. If this problem is not immediately resolved, the next generation of teenager will betotally stubborn. This reality led to a collaboration program between BKKBN and the Government, namely the Generasi Berencana Program. This program is designed as a facilitator for adolescents in order to learn to understand and characterize a healthy life and also to nurture a mature mental behaviorto achievethe adolescent resilience as developing a greatGenerasi Berencana Program. This study aims to determine the effect of adolescent knowledge index on adolescent attitudes. Having this program launched, the government hopes that there will be a good change in the attitude of adolescents in a more positive direction.

Generasi Berencana Programis defined as teenagers and young people who are knowledgeble, good attitude, and polite in behavior as adolescents. They are preparedto plan a great planning in their family life, to carry out the levels of education, career and marriage in accordance with the full planning of the reproductive health cycle. In addition, the main objective of Generasi Berencana program is to facilitate the youth to understand and practice a mature healthy and mental behavior in achieving adolescent resilience as the basis for realizing a The Generasi Berencana Program. (PIK Management Guidelines R / M 2016: 7). The knowledge about The Generasi Berencana Program program is knowledge that is owned by someone about Generasi Berencana programwhich is supported byBKKBN program that aims to foster young people or adolescents in terms of problems that are often faced by adolescents such asthe problems on the Three Risks in Adolescent Reproductive Health (TRIAD KKR) which include Sexuality, Drug,HIV / AIDS, the low level of adolescent knowledge about Adolescent Reproductive Health and also the media for women's first marriage age is still relatively low at 19.8 years.

According to Utami (2015), attitude is a tendency to like or dislike an object, person, institution, or event. The main character of attitude is evaluative, like proactiveor contradictory, like or dislike. Attitude is not behavior but it is a tendency to behave in certain ways towards the object of attitude. A person's attitude towards an object or thing will appear if he has taken an action. So the attitude cannot be seen if there is no activity / action. From this definition, we can understand that through attitude we will be able to detector understand someone's behavior.

\section{Research Method}

This study used a combination method approach using a sequential explanatory design, in the first stage, the researcher used quantitative methods and in the second stage used qualitative methods (Sugiyono, 2013). According to McMillan \& Schumaher, (2010) "sequential explanatory design in which quantitative data is collected first, and depending on its results, qualitative data are gathered to elaborate, elaborate on, or explain the quantitative findings" (McMillan \& Schumaher, 2010). In sequantial explanatory design, the quantitative data is collected first, and depending on the results, qualitative data is collected to explain or describe the results of quantitative data. This study used a descriptive method with a cross-sectional survey approach. This type of descriptive research focused on the disclosure of causal influences between adolescent knowledge variables about the generasi berencana program (GenRe) (X) on Adolescent Attitudes (Y).

Data collection in this study was conducted in two stages, the first stage; distributing questionnaires to 150 adolescents in the provincial capital of Banda Aceh, endemic areas of cases related to TRIAD KKR namely North Aceh or Lhokseumawe City, and border areas namely Aceh Tamiang or Langsa City. Each research area was distributed as many as 50 questionnaires. Second stage; after the results of the questionnaire were analyzed, the researchers selected several representatives of adolescents to be interviewed in depth related to the influence of adolescent knowledge about the generasi berencana program on the attitudes of the teens studied.

The populations in this study those who are considered to know about the data to be studied. The unit analysis taken from the target population in this study were adolescents, namely high school students and students from existing schools or campuses PIK in the Banda Aceh area (capital), North Aceh or Lhokseumawe City (Case Endemic) and Langsa City (Border). The sampling technique used is the nonprobability sampling technique. Nonprobability technique is a technique used for sampling from a population by not providing equal opportunities for all members of the population to be sampled. The type of sampling technique used in nonprobability is purposive sampling. The taking of purposive sampling is for adolescents with criteria where their education has already been socialized about the generasi berencana program.

Questionnaires that were used as a variable measurement tool are independently developed by researchers by referring to the indicators of each variable. The questionnaire was made with a modified Likert scale model. This questionnaire contains a number of questions posed to adolescents namely high school students and students from the regions whose samples are related to the influence of adolescent knowledge about the generasi 
berencana program on adolescent attitudes. Interviews were conducted after the results of the data from the questionnaire were analyzed. In this case, the question that will be submitted by the researcher is based on the questions in the questionnaire, with the aim of confirming whether the relevant data obtained from the questionnaire with the results of the interview and strengthening the data from the questionnaire. Giving a score for each item statement used a Likert scale with an interval scale that can indicate the distance between one data to another data and has the same weight.

Data analysis in this study was carried out using the SPSS application. Validation testers in this study used the Pearson product moment method. In the SPSS program to test the validity of an indicator on a variable by looking at the value of correlation for each construct indicator. The value of Correlation must exceed 0.3 . Reliability testing was undertaken by looking at the cronbach's alpha value. The cronbach's alpha value is greater than 0.7 for confirmatory research and 0.6-0.7 for exploratory research. cronbach's alpha for values below 0.5 have low reliability, values 0.5-0.7 have moderate reliability, 0.7-0.9 have high reliability, and above 0.9 have perfect reliability (Hilton \& Brownlow, 2004).

The research data analysis model used in this study was a simple regression analysis model. This analysis model is used to determine the effect of independent variables on dependent variable. To know the correlation among variables by looking at the determination coefficient (R2), essentially measures how far the model's ability in explaining the variation of the dependent variable. Hypothesis examiners using the Multiple Regression approach using SPSS by testing the value of T. According to (Ghozali, 2011: 98-99) the statistical test $t$ on the basis shows how far the influence or independent variables individually explain the variation of the dependent variable.

\section{Results and Discussions}

The population in this study were adolescents aged 16-24 years. The samples of this study were students from schools who were familiar with the $P I K B K K B N$ socialization. The characteristics of respondents in the research ii can be seen in Figure 6.1. Itcan be saidthat the most respondents are from high school students as many as 114 people or $73.1 \%$, while for college students show a percentage of $26 \%$ or 42 people. According to the researchers of BKKBN PIK, this socialization is mostly done at the high school level, so that the samples are greatly achieved. Based on these results, it can be concluded that education can also influence the adolescence's knowledge about adolescence generation under the sosialization of PIK BKKBNin schools, so that their knowledge is increasingly raised about adolescence generation. There were 156 respondents in this study, 51 people or $32.7 \%$ were from Banda Aceh, the other 51 people from Lhokseumawe, showing 34.6\%, and as many as 51 people or $32.7 \%$ were from Langsa. It can be concluded that the nine samples from the area where the sample is taken are the same number of samples.

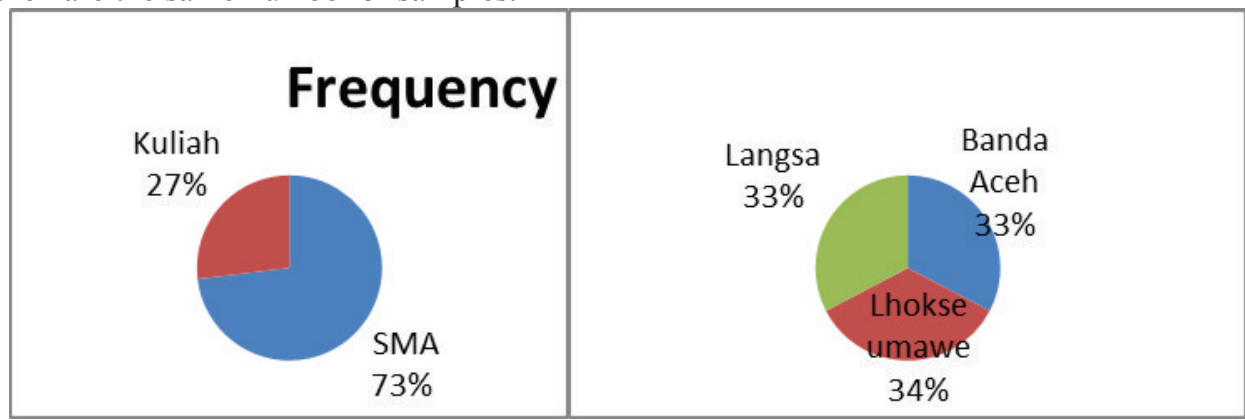

The lowest total answer result of Knowledge variable is 47. The highest total answer of Knowledge variable is 92. The lowest total answer result on Attitude variable is 51 and the highest is 125 . It can answer the lowest differentanswer of knowledge around $50 \%$ and the knowledgevarience is 60.79 and the differentrange of attitudebetween the the lowest and highest answer is more than $50 \%$ and the varience in attitude is 122.47 . It can be concluded that the variation of knowledge and attitudes in the study varies greatly.

\section{Validity and Reliability of Research Variable Instruments}

The result of validity test indicator of kknowledge's variablilitythrough 20 questions represented knowledge variables (research instruments) is valid, because the correlation value of each factor is positive and the amount is 0.30 and above all. Moreover, the result of validity test of Attitude is concerned to 25 questions representing attitude variables (research instruments) is also valid, because the correlation value of each factor is positive and the amount is 0.30 and above all. Hence, the trial of the research instrument is 45 valid statements. The rreliability test results of Cronbach's alpha Knowledge shows 0.742 and the Cronbach's alpha score 0.875 . This shows a good reliability.

The testing model in the study usedlinear regression analysis. The regression model used is as:

$$
\mathrm{Y}=31,487+0.908 \mathrm{X}
$$

The meaning of the linear regression equation above is: The constant of 31,487 states that if Knowledge 
does not exist,so Attitude is 31,487. Regression coefficient Knowledge of 0.908 states that every increase in knowledge of one unit will increase adolescent attitudes by 0.908 assuming other variables remain.

The coefficient of determination is intended to find out how much the ability of the model to explain the dependent variable. If the coefficient of determination (R2) is greater or closer to 1, it can be said that the ability of the independent variable $(\mathrm{X})$ is large against the dependent variable $(\mathrm{Y})$. The Determination Coefficient Test results obtained $\mathrm{R}$ square value of 0.640 , this means $64 \%$ of the variation of the dependent variable adolescent attitudes can be explained by the independent variables of adolescent knowledge about Genres while the remaining $36 \%(100 \%-64 \%)$ is explained by other variables not used in this research.

T-test testing is used to show how far the influence of one independent variable on the dependent variable. The value of $t$ table for probability 0.05 at the free degree $n=156$ is 1.660 . Thus, the results of the $t$-test can be explained as follows: The results of the calculation of the $t$ - test are partially obtained by the value of $t$ count Knowledge of 10.330 with a significant value of 0.000 . The value of $t$ count $>t$ table or $10.330>1.660$ then Ha is accepted, meaning that Youth Knowledge about adolescent generationinfluences the Attitude of Acehnese Youth

The results of the analysis show that the Youth Knowledge about adolescent generation(Genre) influences Acehnese Youth Attitudes with t count $>$ t table or $10.33>1.660$ and shows significant value of $0,000<0.05$. The results of this study are the same as the results of researchers who were presented by Sari in 2011 whose title was "The Influence of Knowledge on Adolescent Attitudes toward Sexually Transmitted Diseases due to sexual relations in MAN Mojokerto. The results states that the knowledge of adolescents greatly influences the formation of adolescent attitudes in appreciating what they know. Moreover, Knowledge can shape what information is known in implementing in everyday life, so that they can shape their attitudes. The results of this study are consistent with the opinion of Barber et al. in 2009, which was presented in the research of Ayustiarini et al. in 2017, which states that an objective knowledge possessed by a person that can lead a positive effect and significant attitude in purchasing.

The results of this study were also examined in the form of interviews which resulted in the PIK Program. This program is very positive among adolescents so far. Based on the results of the research, many teenagers asked to increase a more $P I K$ program such as the results presented by one of the respondents from Lhokseumawe,

"I want the PIK program in Senior High School 5 Lhokseumawe to be improved at school, because I see a lot of students smoking in the school".("Saya ingin program PIK di SMA Negeri 5 Lhokseumawe ditingkatkan di sekolah, karena banyak saya lihat di sekolah siswa yang merokok”).

And the other perspectives came from one of the participants from Langsa,

"It is expected that the PIK is not just a name to build a quality generation of the nation. But it directly plunges into the field like opening a small organization in every corner, school, college or workplace ".("Diharapkan agar PIK tersebut bukan hanya sebuah nama untuk memangun generasi bangsa yang berkualitas.Tetapi langsung terjun kelapangan seperti membuka organisasi kecil di setiap pelosok, sekolah, kuliah ataupun tempat kerja").

Therefore, it can be concluded that the result of this study under the PIK program is to prevent an early getting married based on the opinion said by one of the respondents of Lhokseumawe, too.

"In my opinion the GenerasiBerencana program is a good program for adolescents in carrying out mature family life. And this program can prevent early marriages that have an impact on the education of adolescents. The GenerasiBerencana program can prevent sexual crimes and prevent drug use. " (" Menurut saya program Genre adalah program yang bagus untuk para remaja dalam melaksanakan kehidupan berkeluarga secara matang. Dan program ini dapat mencegah pernikahan dini yang berdampak pada pendidikan para remaja. Genre dapat menjegah terjadinya kejahatan seksual dam pencegahan menggunakan narkoba”).

\section{Conclusion}

1. Adolescent Knowledge About Generasi Berencana Program influences the Attitudes of Acehnese adolescents.

2. The PIK program is a very positive program among adolescents. Based on the results of the research, many adolescents asked to increase the PIK program again.

3. This PIK program can prevent the occurrence of early marriage and prevention of using drugs.

\section{References}

[1] Ali, M dan Asrori, M. (2008). Psikologi remaja. Jakarta : Bumi Aksara

[2] BKKBN. (2016). Pedoman Pengelolaan Pusat Informasi dan Konseling Remaja dan Mahasiswa (PIK R/M). Jakarta Timur: Direktorat Bina Ketahanan Remaja.

[3] Daud, M. K dan Dasmidar. (2017). Program Generasi Berencana BKKBN Provinsi Aceh dan korelasinya dengan adat berguru dalam masyarakat (studi kasus di Kecamatan Kutapanjang Kabupaten Gayo Lues). Jurnal Hukum Keluarga dan Hukum Islam, 1 (1), 
[4] Direktorat Remaja dan Perlindungan Hak-Hak Reproduksi. (2006). Panduan Pengelolaan Pusat Informasi \& Konseling Kesehatan Reproduksi Remaja (PIKKRR). Jakarta : BKKBN.

[5] Diyah Widyastuti, Agustin Syamsianah, Nuke Devi Indrawati, Tingkat Pengetahuan Ibu Hamil Tentang Inisiasi Menyusu Dini, Di Wilayah Kerja Puskesmas Bawang Kabupaten Batang, Universitas Muhammadiyah Semarang, 2010

[6] McMillan, J.H \& Schumacher, S. (2010). Research in Education. New Jersey: Pearson.

[7] Notoatmodjo, Soekidjo. (2003). Ilmu Kesehatan Masyarakat : Prinsip-prinsip. Dasar. Jakarta : PT. Rineka Cipta.

[8] Priyanti, Sari.(2011). Pengaruh Pengetahuan terhadap sikap remaja terhadap penyakit yang menular akibat hubungan seksual di MAN Mojokerto. Hospital Majapahit

[9] Rozaini. Nasution, '(Paper Teknik Sampling)’ ,Universitas Sumatera Utara.

[10] Rusiadi, Nur Subiantoro dan Rahmat Hidayat, (2014), Metode Penelitian: Konsep, Kasus dan Aplikasi SPSS, Eview, Amos, Lisrel, Cet. 2. Penerbit USU, Medan

[11] Saifudin Azwar, Metode Penelitian, (Yogyakarta : Pustaka Pelajar, 2011), Hal.5

[12] Sarwono, Jonathan.2012.Metode Riset Skripsi Pendekatan Kuantitatif(Menggunakan Prosedur SPSS).Jakarta: PT. Elex Media Komputindo. Sarwono, S. (2011). Psikologi Remaja. Jakarta : PT. Rajagrafindo Persada.

[13] Shahrzad Shahriari, Mohammadreza Shahriari, And Saeid Gheiji, "E- Commerce And It Impacts On Global Trend And Market.” International Journal Of Research - Granthaalayah, Vol. 3, No. 4(2015): 49-55

[14] Singgih. (1998), Abu Ahmadi. (2001), Khayan. (1997), Nasution. (1999), Wied Hary. (1996). Faktor-Faktor yang Mempengaruhi Pengetahuan. Diakses 19 April 2010, From http://forbetterhealth.wordpress.com

[15] Situmorang. James, '(Pemanfaatan Internet Sebagai New Media Dalam Bidang Politik, Bisnis, Pendidikan Dan Sosial Budaya)', '(Jurnal Administrasi Bisnis)', Parahyangan.

[16] Somantri and S. A. Muhidin.(2006).Aplikasi Statistika Dalam Penelitian. Bandung: Pustaka Setia

[17] Sudjana. 2010. Metodelogi Statistika. Bandung : Tarsito Sugiyono. 2011. Statistika Untuk Penelitian. Bnadumh : Alfabeta. Sugiyono. 2013. Metode Penelitian Kombinasi. Bandung: Alfabeta

[18] Sugiyono.2013.Metode Penelitian Kombinasi (Mixed Methods). Bandung : Alfabeta.

[19] Sugianto, Johan, "(Penerapan E-Lectronic E-Commerce Sebagai Upaya Meningkatkan Penjualan Produk)", "(Sumatera Utara, Proposal Penelitian)".

[20] Rini, Ayu S., Sukatmadja, I P. G., Giantari, I Gst. A. Kt.,(2017). Pengarug Pengetahuan Lingkungan dan kepedulian Lingkungan Terhadap Sikap dan niat beli produk hijau "The Body Shop" di Kota Denpasar. Jurnal Ekonomi dan Bisnis Universitas Udayana : Denpasar

[21] Utami, D. D. Y. (2015). Penyuluhan Program BKKBN mengenai generasi berencana (GenRe) dan sikap remaja, jurnal simbolika, 1 (2).

[22] Wibowo. Radetya, '(Kesuksesan E-Commerce (Onlineshopping) Melalui Trust Dan Customer Loyalty)', Malang.

[23] Wirdasari, Dian. '(Teknoloi E-Commerce Dalam Proses Bisnis)', '(Lppm-Stmik Triguna Dharma)', '(Jurnal Saintikom Vol 7/No.2/ Agustus 2009)'. 